Article

\title{
Enhancing the Antioxidant Ability of Trametes versicolor Polysaccharopeptides by an Enzymatic Hydrolysis Process
}

\author{
Mei-Hsin Jhan ${ }^{1}$, Ching-Hua Yeh ${ }^{1}$, Chia-Chun Tsai ${ }^{1}$, Ching-Tian Kao ${ }^{2}$, Chao-Kai Chang ${ }^{3}$ and \\ Chang-Wei Hsieh 1,2,* \\ 1 Department of Medicinal Botanicals and Health Applications, Da-Yeh University, No.168, Xuefu Rd., \\ Dacun Township, Chang-Hua 51591, Taiwan; mickey810514@gmail.com (M-H.J.); \\ judyyeh@mail.dyu.edu.tw (C-H.Y.); jasmine312034@hotmail.com (C-C.T.) \\ 2 Department of Pediatrics, Cheng Ching General Hospital, Taichung 400, Taiwan; \\ monster0936@yahoo.com.tw \\ 3 Biotechnology Research Center, Da-Yeh University, 168 University Rd, Dacun, Chang-Hua 51591, Taiwan; \\ kai0913077636@gmail.com \\ * Correspondence: welson@mail.dyu.edu.tw; Tel.: +886-4-8511-888 (ext. 1790); Fax: +886-4-8511-349 \\ Academic Editor: Derek J. McPhee \\ Received: 20 June 2016; Accepted: 6 September 2016; Published: 10 September 2016
}

\begin{abstract}
Polysaccharopeptides (PSPs) are among the main bioactive constituents of Trametes versicolor (T. versicolor). The purpose of this research was to investigate the antioxidant activities of enzymatic hydrolysates obtained from T. versicolor polysaccharopeptides by $80 \mathrm{U} / \mathrm{mL} \beta$-1,3-glucanase (PSPs-EH80). The half-inhibitory concentration ( $\left.\mathrm{IC}_{50}\right)$ of PSPs-EH80 in metal chelating assay, ABTS and DPPH radical scavenging test results were $0.83 \mathrm{mg} / \mathrm{mL}, 0.14 \mathrm{mg} / \mathrm{mL}$ and $0.52 \mathrm{mg} / \mathrm{mL}$, respectively, which were lower than that of PSPs-EH $20 \mathrm{U} / \mathrm{mL}$. The molecular weights of the PSPs-EH80 hydrolysates were 300, 190, 140 and $50 \mathrm{kDa}$, respectively, and the hydrolysis of polysaccharides by $\beta-1,3$-glucanase did not change the original functional group. PSPs-EH80 reduced the reactive oxygen species (ROS) content at least twice that of treatment without PSPs-EH80. In addition, an oxidative damage test showed that PSPs-EH80 can improve HaCaT cell survival. According to our results, PSP demonstrates the potential of anti-oxidative damage; besides, enzyme hydrolysis can improve the ability of the PSP.
\end{abstract}

Keywords: polysaccharopeptides (PSPs); enzymatic hydrolysates; antioxidant activities

\section{Introduction}

Trametes versicolor ( $T$. versicolor) is a basidiomycete that has been used as a traditional medicinal mushroom [1]. Polysaccharides from T. versicolor have been reported to exhibit excellent bioactivity [2]. The protein-bound polysaccharides, polysaccharopeptides (PSPs), have been reported to be nontoxic with prolonged use in the treatment of cancers by suppressing DNA/RNA synthesis and enhancing the immune function [3-5].

The biological activities of polysaccharides are related to molecular weight, structure and viscosity [6,7]. To date, research has proved that the molecular weight of polysaccharides has a great influence on their biological activities [8]. For instance, after acidic degradation, low molecular weight polysaccharides exhibit stronger antioxidant activities than high molecular weight polysaccharides $[9,10]$. Conceptually, the degradation of high molecular weight polysaccharides might improve their poor penetration capability on cell membranes, thereby enhancing their activities [11].

Several chemical and physical methods, including enzymatic hydrolysis, acid hydrolysis and oxidative degradation, can break polysaccharides into lower molecular weight units [12,13]. 
Acid hydrolysis requires a long reaction time; it changes the structure of sugar units and can destroy necessary bioactive groups. Enzymatic hydrolysis can specifically cleave the glycosidic bonds in a polysaccharide chain [10,14]. Glucanases can be divided into exo- and endo- depending on the different positions of the glucan bonds they hydrolyze [15]. $\beta-1,3-$-Glucanase, an endoglucanase widespread in bacteria, yeast, fungi and plants, hydrolyzes 1,3 bonds, producing oligosaccharides of different molecular weights.

In this study, to specifically hydrolyze $\beta$ - $(1 \rightarrow 3)$-glycosidic linkages in PSPs, $\beta-(1 \rightarrow 3)$-D-glucanase was used to obtain enzymatic hydrolysates from $T$. versicolor PSPs. The antioxidant activities and functional groups of different molecular weight enzymatic hydrolysates were analyzed. The use of enzymatic hydrolysates from T. versicolor PSPs to counter oxidative damage by human keratinocytes $(\mathrm{HaCaT})$ was also discussed in relation to evaluating the possibility of its development for use in the skin care industry.

\section{Results and Discussion}

\subsection{Metal Chelating Activity}

Ferrous ions $\left(\mathrm{Fe}^{2+}\right)$ accelerate free radical accumulation in cells via the Fenton reaction $\left(\mathrm{Fe}^{2+}+\mathrm{H}_{2} \mathrm{O}_{2} \rightarrow \mathrm{Fe}^{3+}+\mathrm{OH}^{-}+\bullet \mathrm{OH}\right)$ [16]. Ferrozine can form complexes with $\mathrm{Fe}^{2+}$, disrupting the complex formation and resulting in the decreased red color of the complexes in the presence of other chelating agents [17]. We determined the antioxidant activities of PSPs, PSPs-EH20 and PSPs-EH80 using the $\mathrm{Fe}^{2+}$ chelating test. The ferrous ion chelating ability of PSPs-EH80 was better than that of PSPs-EH20 and PSPs, as shown in Figure 1. Relevant research has indicated that the Enteromorpha prolifera and Ganoderma lucidum polysaccharides of low molecular weight are more efficacious than those of higher molecular weight with respect to their $\mathrm{Fe}^{2+}$ chelating ability $[10,18]$. We indicate that the $\mathrm{IC}_{50}$ of the PSPs-EH80 hydrolyzed by enzyme is $0.83 \mathrm{mg} / \mathrm{mL}$, which is $2-4$ times better than Enteromorpha prolifera ( $\mathrm{IC}_{50}$ is $2 \mathrm{mg} / \mathrm{mL}$ ) and Ganoderma lucidum ( $\mathrm{IC}_{50}$ is $4 \mathrm{mg} / \mathrm{mL}$ ) [10,18].

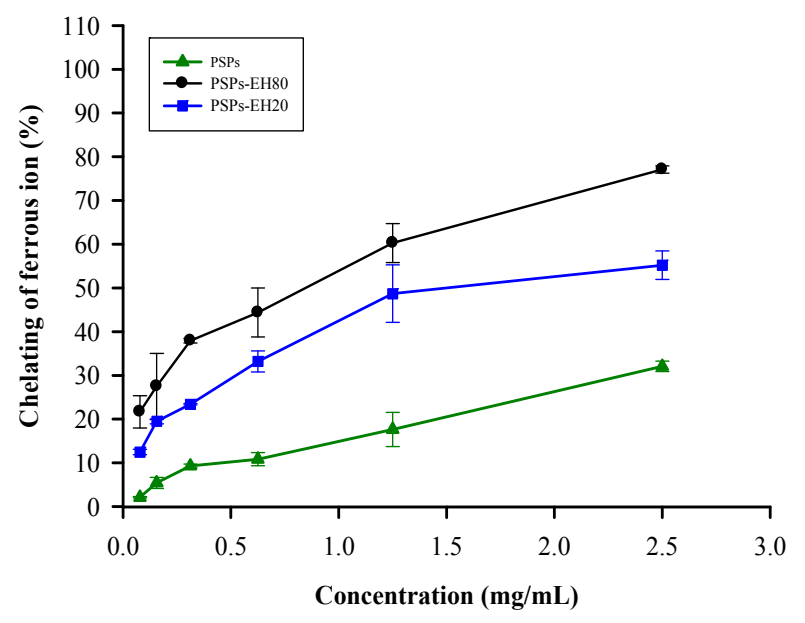

Figure 1. Antioxidant effects of PSPs and PSPs-EH on ferrous ion chelating ability. The ferrous ion chelating ability of PSPs and PSPs-EH was examined by reacting ferrozine with $\mathrm{Fe}^{2+}$; the color change was determined by measuring the absorbance at $562 \mathrm{~nm}$. Error bars represent $\mathrm{SD}(n=3), p<0.05$.

\subsection{ABTS Radical Scavenging Activity}

The ABTS radical scavenging activity assay involves a reversible reduction-oxidation process. We determined the ABTS $\bullet{ }^{+}$scavenging ability of PSPs, PSPs-EH20 and PSPs-EH80 (the scavenging activity at $0.6 \mathrm{mg} / \mathrm{mL}$ is $70 \%, 90 \%$ and $100 \%$, respectively) and found that the $\mathrm{IC}_{50}$ of PSPs-EH80 ABTS $\bullet^{+}$scavenging ability was $0.14 \mathrm{mg} / \mathrm{mL}$, which is lower than that of PSPs-EH20 $\left(\mathrm{IC}_{50}=0.16 \mathrm{mg} / \mathrm{mL}\right)$ and PSPs (Figure 2). Furthermore, the PSPs-EH80 ABTS $\bullet^{+}$scavenging ability 
has a better result than that of the floral mushroom and Schisandra chinensis polysaccharide [19,20]. This result suggests that PSPs-EH80 has a greater ability than PSPs-EH20 and PSPs to neutralize free radicals by accepting or donating an electron to eliminate the unpaired condition due to PSPs-EH80 having a low molecular weight [9]. Some natural polysaccharides are bound to protein or peptide residues, and the PSPs isolated from mushrooms were reported to have better radical scavenging activities [21,22]. Therefore, the radical scavenging activity of PSPs was better than that of polysaccharides. In this study, the ABTS • ${ }^{+}$scavenging ability of PSPs-EH was even better than that of PSPs, which means that the hydrolysates are an effective natural antioxidant.

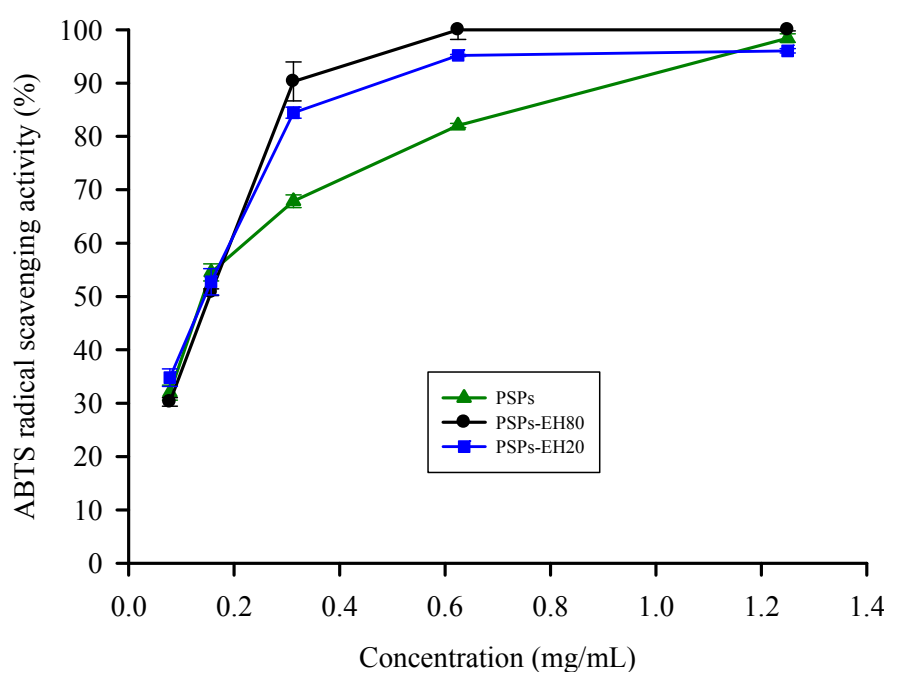

Figure 2. Antioxidant effects of PSPs and PSPs-EH on ABTS ${ }^{+}$radical scavenging activity. The color change was determined by measuring the absorbance at $735 \mathrm{~nm}$. Error bars represent $\mathrm{SD}(n=3), p<0.05$.

\subsection{DPPH Radical Scavenging Activity}

Antioxidants inhibit oxidation chain reactions by providing hydrogen to DPPH radicals. The reaction can be expressed as follows: DPPH $\bullet+\mathrm{AH}$ (antioxidant agent) $\rightarrow \mathrm{DPPH}+\mathrm{HA} \bullet$. The DPPH radical scavenging assay is often used to evaluate the hydrogen-providing ability of antioxidants [23]. The effects of PSPs and PSPs-EH on DPPH radical scavenging were determined as shown in Figure 3. The scavenging activity of PSPs, PSPs-EH20 and PSPs-EH80 is concentration-dependent. The enzymatic hydrolysates show the maximum scavenging (about 90\% inhibition) at $1.2 \mathrm{mg} / \mathrm{mL}$. The results revealed that enzymatic products of PSPs showed more effective DPPH radical activity than did the intact PSPs. Indeed, the DPPH radical scavenging activity of PSPs-EH80 was 2.5-fold higher than that of PSPs, with $\mathrm{IC}_{50}$ value of $0.52 \mathrm{mg} / \mathrm{mL}$. The result could be explained by the fact that the enzymatic hydrolysates, PSPs-EH, could provide more hydrogen than the PSPs to form a stable DPPH-H molecular structure [9].

A previous study used enzymatic hydrolysates of polysaccharides to enhance the antioxidant ability [24]; however, using hydrolysis of specific bond of T. versicolor (mushroom polysaccharide) by $\beta$-1,3-glucanase to reduce the low molecular weight resulted in a 2.5-fold higher capacity. Furthermore, the lowest molecular weight fraction exhibited the highest DPPH radical and hydroxyl radical scavenging activities [25]. Therefore, we analyzed the molecular weight and the functional groups of PSP, as well as the antioxidant capacity of the best PSP-EH80 which has the strongest antioxidant ability, to determine the reason for the hydrolytic influencing the physiological activity. 


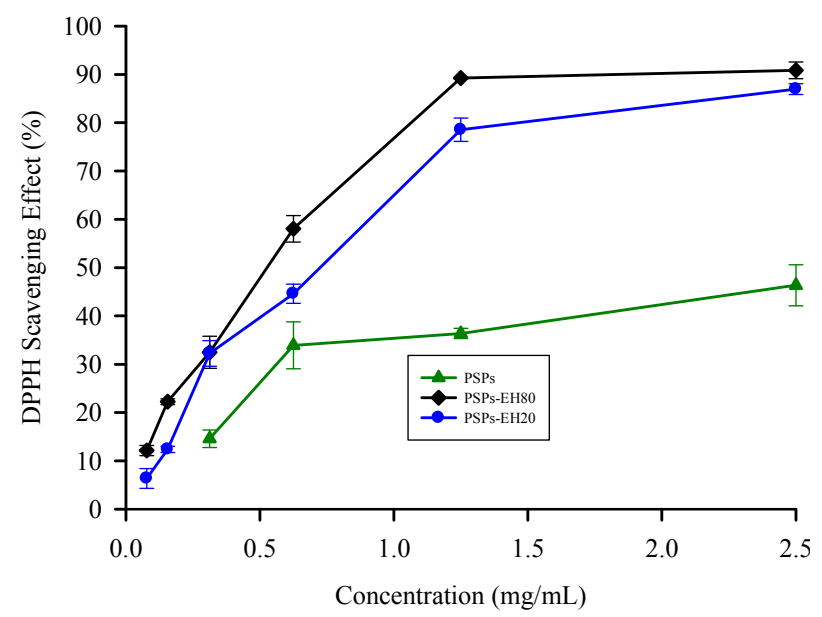

Figure 3. Antioxidant effects of PSPs and PSPs-EH on DPPH radical scavenging activity. The DPPH radical scavenging activity of PSPs and PSPs-EH was examined by reacting with DPPH radical, and the color change was determined by measuring the absorbance at $517 \mathrm{~nm}$. Error bars represent SD $(n=3), p<0.05$.

\subsection{Molecular Weight and FT-IR Spectroscopy}

Comparing the antioxidant activity of molecular weight segments between 6.55 to $256 \mathrm{kDa}$ indicated that the $6.55 \mathrm{kDa}$ segment has the strongest antioxidant activity, meaning the polysaccharide antioxidant activity is related to molecular weight [26]. In addition, in the antioxidant activity test, the antioxidant activity of -EH80 of PSP was significantly higher $(p<0.05)$ than PSP-EH20 and PS; then, the CL-6B gel filtration column was used to analyze the molecular weights of PSP and PSP-EH80. Figure 4 shows that the PSPs showed only one peak, which was about $300 \mathrm{kDa}$, whereas the molecular weight of PSPs-EH80 had four different peaks, at approximately 300, 190, 140 and $50 \mathrm{kDa}$, respectively.

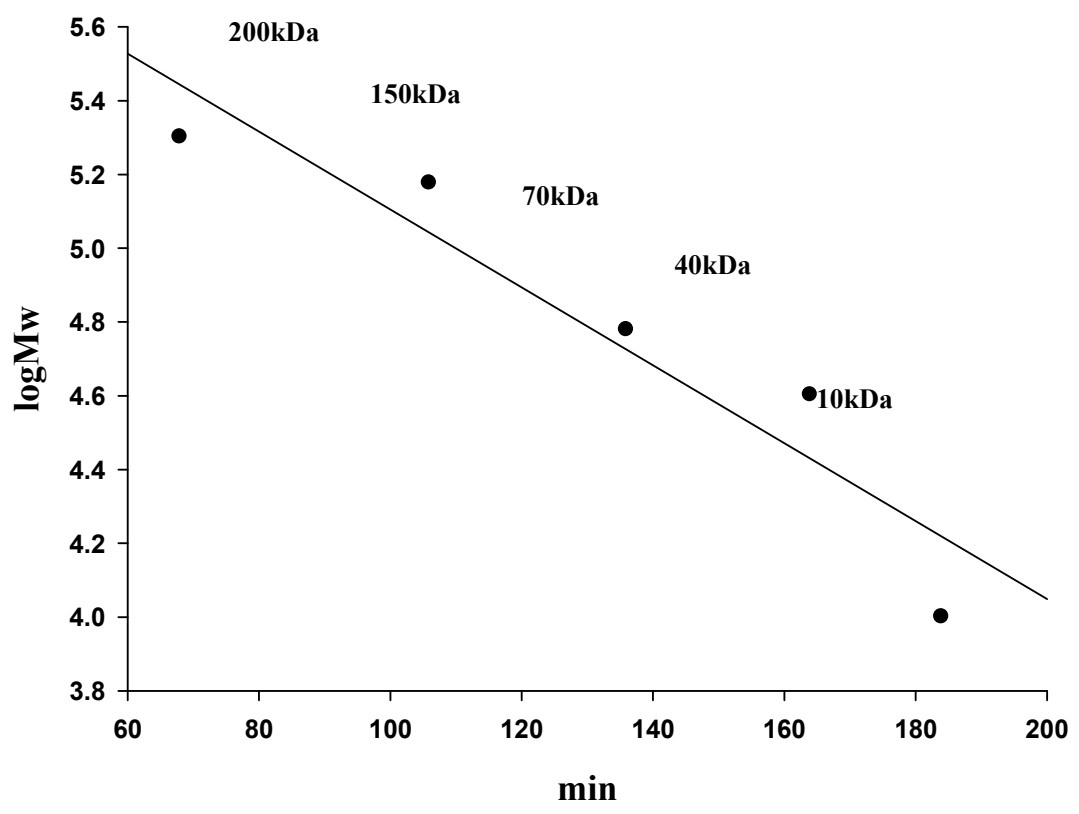

(A)

Figure 4. Cont. 


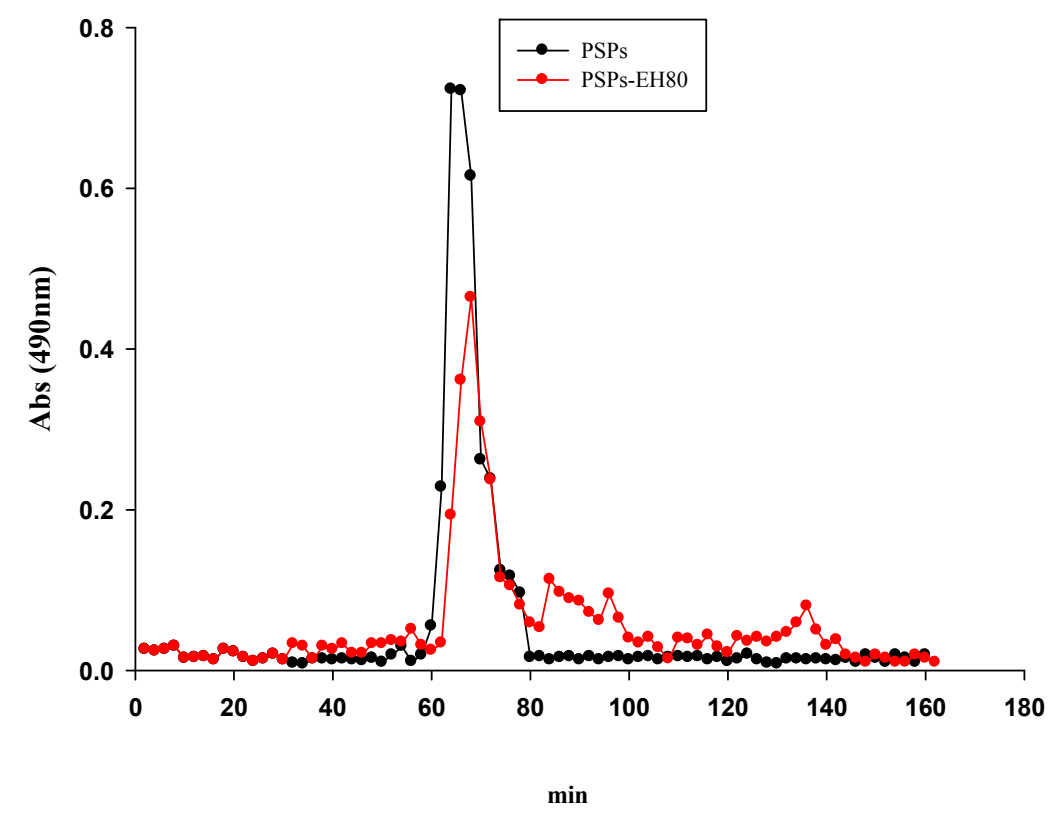

(B)

Figure 4. Gel filtration chromatography of the PSPs and PSPs-EH80 on Sepharose CL-6B. The Sepharose CL-6B was calibrated with different molecular masses of dextran (A). In this column, the PSPs and PSPs-EH80 elution profiles were determined using the phenol-sulfuric acid method (B).

The results revealed that $\beta$-1,3-glucanase can hydrolyze the macromolecules of PSPs into smaller molecules, and that the hydrolysis rate was $38.6 \%$ (Table 1). Our data also showed that the molecular weight of PSPs-EH80 ranged from 50 to $300 \mathrm{kDa}$. We also suggest that the chelating ability of PSPs-EH80 is related to its low molecular weight.

Table 1. Average molecular weight and hydrolysis rate of PSPs and PSPs-EH80.

\begin{tabular}{ccccc}
\hline PSPs Fraction & Peak & $\mathbf{M}_{\mathbf{w}} \mathbf{( k D a )}$ & Area \% & Hydrolysis Rate \\
\hline PSPs & Peak 1 & $300 \mathrm{kDa}$ & 100.0 & $38.6 \%$ \\
\hline PSPs-EH80 & Peak 2 & $300 \mathrm{kDa}$ & 61.4 & \\
& Peak 3 & $190 \mathrm{kDa}$ & 18.8 & \\
& Peak 4 & $140 \mathrm{kDa}$ & 7.2 & \\
& Peak 5 & $50 \mathrm{kDa}$ & 12.6 & \\
\hline
\end{tabular}

We identified the organic groups in PSPs and PSP-EH80 using FT-IR spectroscopy. In Figure 5, the band at $3490 \mathrm{~cm}^{-1}$ represents the stretching vibration of $\mathrm{O}-\mathrm{H}$ bonds in constituent sugar residues, while the band at $2850 \mathrm{~cm}^{-1}$ is associated with the stretching vibration of $\mathrm{C}-\mathrm{H}$ bonds in the sugar ring. The O-H and C-H bonds were detected in both the PSPs and PSP-EH80. The characteristic absorption band that appeared at $1630 \mathrm{~cm}^{-1}$ was assigned to the stretching of $\mathrm{C}=\mathrm{O}$ bonds; the band at $1114 \mathrm{~cm}^{-1}$ is associated with the stretching vibration of $\mathrm{C}-\mathrm{O}$ bonds. The $\mathrm{C}=\mathrm{O}$ and $\mathrm{C}-\mathrm{O}$ bonds exist in both PSPs and PSPs-EH80. The carbohydrates show a high absorption band between the $1200 \mathrm{~cm}^{-1}$ and $850 \mathrm{~cm}^{-1}$ regions, referred to as the fingerprint region, where the position and intensity of the bands are specific for every polysaccharide, enabling the identification of major chemical groups in polysaccharides $[27,28]$. Our results confirmed the polysaccharide pattern in PSPs and PSPs-EH80 (Figure 4).

The C-O-C and C-O-H bonds shown at $1047 \mathrm{~cm}^{-1}$, representing a pyran structure, were detected in both the PSPs and PSPs-EH80. According to the spectra in Figure 5, enzymatic digestion did not 
damage the active site of the sugar chains, and the functional groups of PSPs-EH80 were not changed and remained similar to those of the PSPs.

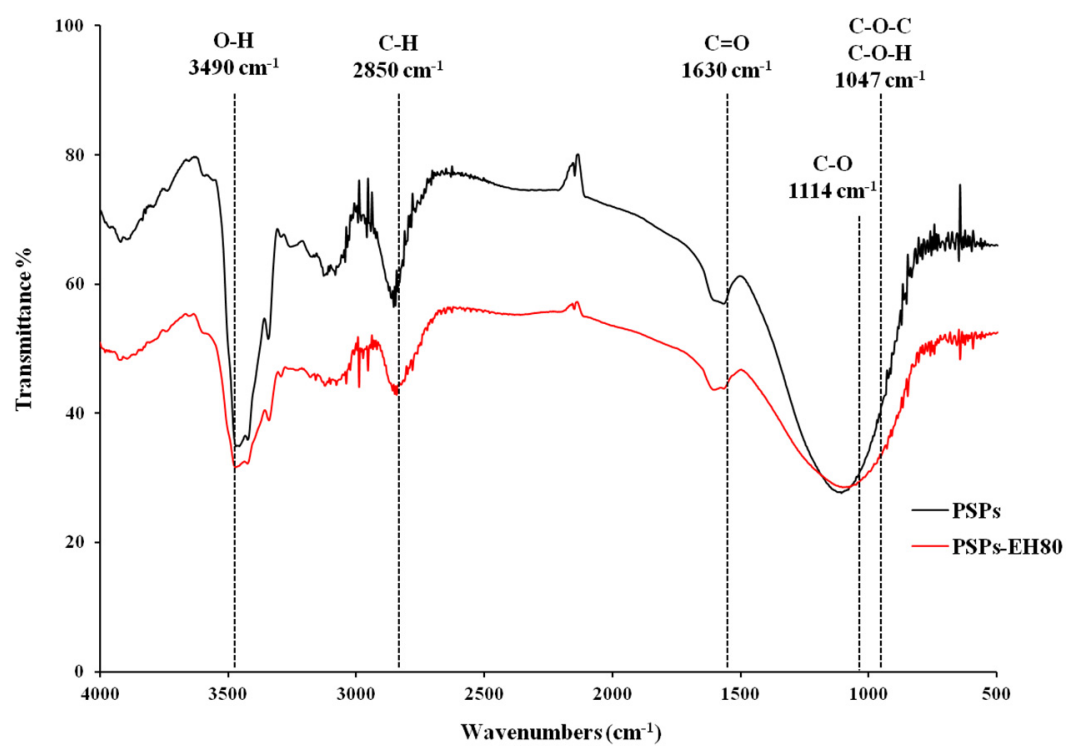

Figure 5. IR spectra of PSPs and PSPs-EH80.FT-IR assignments, wave number $\left(\mathrm{cm}^{-1}\right)$ : 3490 stretching vibration (str) of O-H, 2850str of C-H, 1630str of C=O and 1114str of C-O; 1047 is representative of $\mathrm{C}-\mathrm{O}-\mathrm{C}$ and $\mathrm{C}-\mathrm{O}-\mathrm{H}$.

\subsection{Effect of PSPs or PSP-EH80 on Cell Viability and ROS Assay in HaCaT Cells}

The cell viability of PSPs or PSP-EH80-treated HaCaT cells was analyzed by a MTT assay. The viability of AAPH-treated cells was $40 \%$ lower than that of the control group. PSPs showed little preventive effect on AAPH-induced cell death. PSP-EH80 treatment $(75,100$ and $125 \mu \mathrm{g} / \mathrm{mL})$ increased the viability of AAPH-treated cells in a dose-dependent manner, which was $70 \%, 73 \%$ and $78 \%$, respectively (Figure 6).

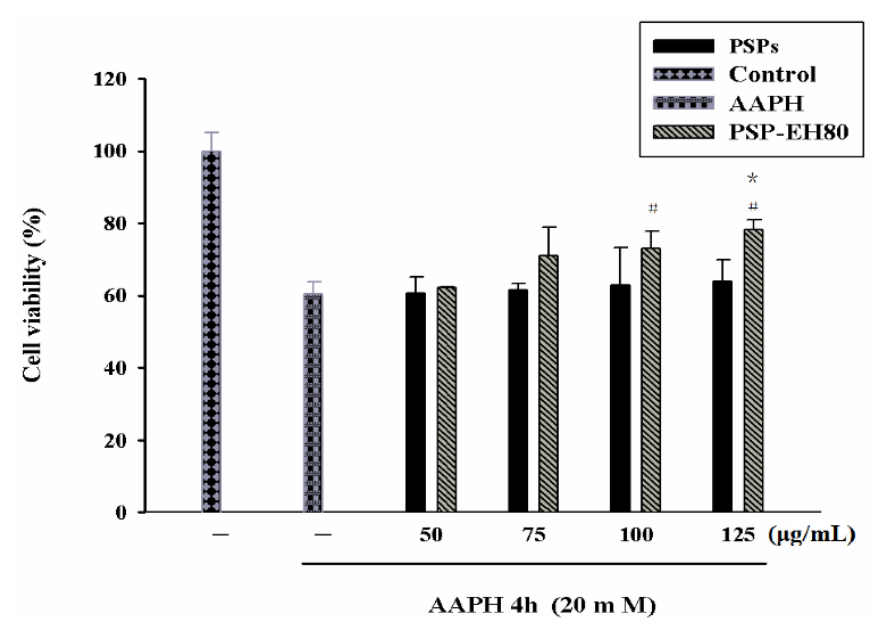

Figure 6. HaCaT cell survival rates after treatment with PSP, PSP-EH80 and AAPH. HaCaT cells $\left(1 \times 10^{4}\right)$ were pre-incubated for $24 \mathrm{~h}$ and the cells treated with varying concentrations $(\mu \mathrm{g} / \mathrm{mL})$ of PSPs and PSPs-EH80 for $24 \mathrm{~h}$. AAPH $(20 \mathrm{mM})$ was then added for $4 \mathrm{~h}$ at $37^{\circ} \mathrm{C}$ in a $5 \% \mathrm{CO}_{2}$ atmosphere. The absorbance was measured at $570 \mathrm{~nm}$ by ELISA. The results are represented as percentages of the control. * $p<0.05$ compared with the PSPs group; ${ }^{*} p<0.05$ compared with the AAPH group. 


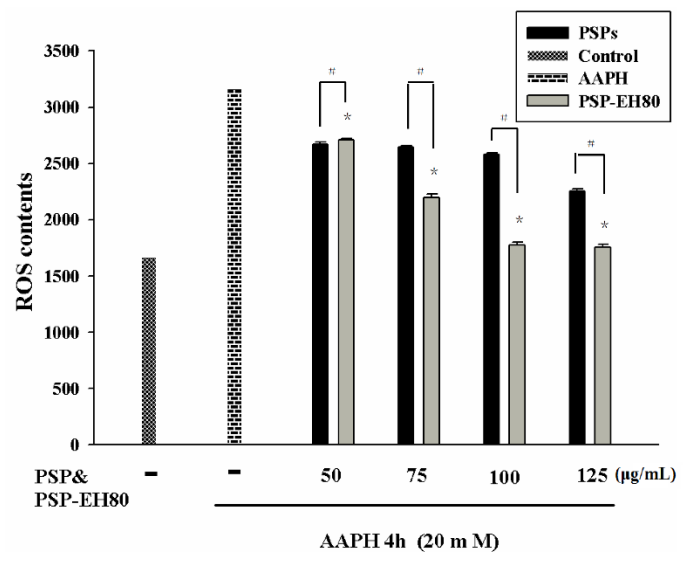

(a)
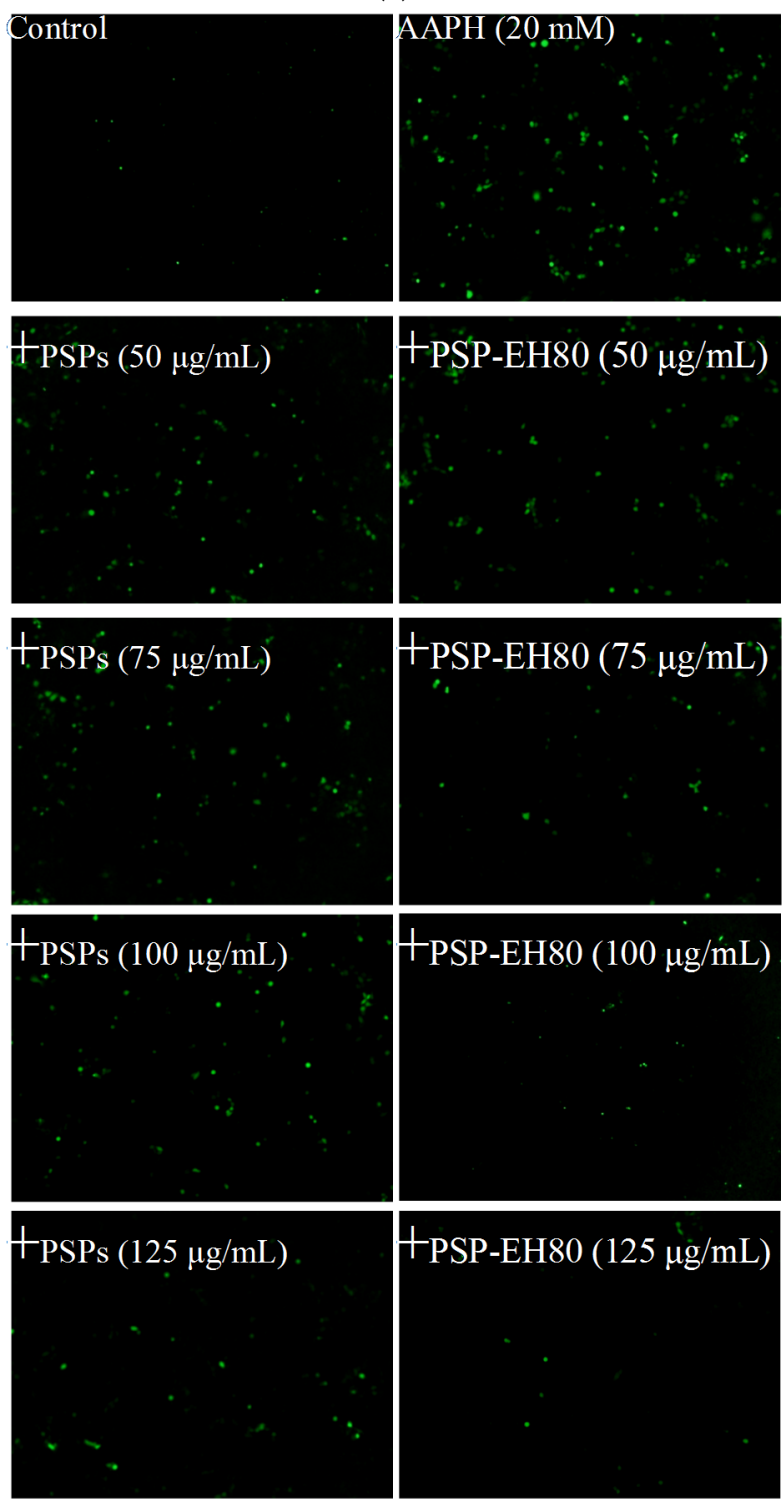

(b)

Figure 7. HaCaT cell fluorescence after treatment with PSPs, PSPs-EH80 and AAPH. HaCaT cells $\left(3 \times 10^{5}\right)$ were pre-incubated for $24 \mathrm{~h}$ and the cells treated with varying concentrations $(\mu \mathrm{g} / \mathrm{mL})$ of PSP and PSPs-EH80 for $24 \mathrm{~h}$. AAPH $(20 \mathrm{mM})$ was then added for $4 \mathrm{~h}$ at $37^{\circ} \mathrm{C}$ in a $5 \% \mathrm{CO}_{2}$ atmosphere. (a) The fluorescence intensity of the DCF-stained cells was quantified. ${ }^{*} p<0.05$ compared with the PSPs group; ${ }^{\#} p<0.05$ compared with the AAPH group. (b) The intracellular ROS level was indicated by DCF fluorescence, and measured using fluorescence microscopy. 
Our data suggest that the PSP-EH80 has a better protective effect than PSP on AAPH-induced cell death. Previous studies have reported that AAPH induces oxidative stress through the intracellular elevation of ROS in a variety of cells, including macrophages and keratinocytes [29-31]. Increased ROS can break the intracellular antioxidant defense system and cause cell damage and death [32]. In the present study, the oxidative stress induced by AAPH in HaCaT cells was determined by intracellular ROS generation using a DCFH-DA assay. As shown in Figure 7a,b, AAPH increased ROS generation by 2 -fold in the HaCaT cells when compared with the control cells. PSP-EH80 treatment (50-125 $\mu \mathrm{g} / \mathrm{mL}$ ) significantly inhibited AAPH-induced ROS generation in a dose-dependent manner. Our results suggest that PSP-EH80 could prevent cell death induced by AAPH through inhibiting ROS generation. A previous study indicated that polysaccharides with low molecular weight showed better antioxidative ability [11]. Our results also found that the antioxidative effect of PSP-EH80 was better than that of PSPs.

\section{Materials and Methods}

\subsection{Materials and Components}

The fruiting bodies of Trametes versicolor (BCRC No.: 35683) were provided by Da Yeh University Biotechnology Research Center; the method of solid-state cultures fruiting bodies

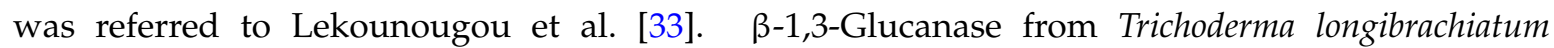
(CAS Number 9044-93-3), 2,2'-azobis(2-amidinopropane) dihydrochloride (AAPH), 3-(4,5-dimethylthiazol-2-yl)-2,5-diphenyltetrazolium bromide (MTT), and 2',7'-dihydrofluorescein diacetate (DCFH-DA) were purchased from Sigma Chemical Co. (St. Louis, MO, USA). Sepharose CL-6B was purchased from General Electric Healthcare (Chicago, IL, USA). Potassium bromide (IR grade) was purchased from Scharlau Chemie S.A. (Sentmenat, Spain). All of the other chemicals used in this study were of analytical grade and were obtained commercially.

\subsection{Preparation of PSPs from T. versicolor}

The method had been previously used by Huang et al. [2] and Sun et al. [34], with modifications. The fruiting bodies of T. versicolor were extracted three times with $80 \%$ ethanol under reflux at $75^{\circ} \mathrm{C}$ for $6 \mathrm{~h}$ to defat them and remove some colored materials, oligosaccharides, lipids and some small molecular materials. The pretreated samples were separated from the organic solvent through a nylon cloth. Each $10 \mathrm{~g}$ of dried pretreated sample was extracted by $200 \mathrm{~mL}$ water at $95{ }^{\circ} \mathrm{C}$ for $2.5 \mathrm{~h}$. The water extraction solutions were separated from the insoluble residue by centrifugation $(2000 \times g$ for $10 \mathrm{~min}$ at $20{ }^{\circ} \mathrm{C}$ ) to remove protein (modified Sevage method) and then precipitated by the addition of dehydrated alcohol to a final concentration of $80 \%(v / v)$. The precipitates collected by centrifugation $\left(2000 \times g\right.$ for $10 \mathrm{~min}$ at $\left.20^{\circ} \mathrm{C}\right)$ were washed with dehydrated alcohol three times and dried under reduced pressure.

\subsection{Enzymatic Hydrolysis of PSPS}

Water extract PSPs were dissolved with $0.1 \mathrm{M}$ sodium acetate buffer solution ( $\mathrm{pH} 5$ ) and made into $2 \mathrm{mg} / \mathrm{mL}$ PSPs concentrated solution. Then, $5 \mathrm{~mL}$ of $\beta$-1,3-glucanase enzyme (20 and $80 \mathrm{units} / \mathrm{mL}$, where one unit was defined as the production of $1 \mathrm{mg}$ of glucose equivalent per min) was added to $5 \mathrm{~mL}$ of $2 \mathrm{mg} / \mathrm{mL}$ PSPs solution, and the final PSPs concentration was $1 \mathrm{mg} / \mathrm{mL}$. It was mixed well and incubated at $40{ }^{\circ} \mathrm{C}$ for $2 \mathrm{~h}$ to hydrolyze the PSPs, followed by enzyme inactivation for $5 \mathrm{~min}$ at $95{ }^{\circ} \mathrm{C}$ to terminate the reaction. The T. versicolor PSPs enzymatic hydrolysates $20 \mathrm{U} / \mathrm{mL}$ (PSPs-EH20) and $80 \mathrm{U} / \mathrm{mL}$ (PSPs-EH80) were then stored at $-30{ }^{\circ} \mathrm{C}$ [35]. The antioxidant ability of PSPs, PSPs-EH-20 and PSPs-80 was assessed. 


\subsection{Metal Chelating Activity Assay}

Each sample (PSPs, PSPs-EH20 and PSPs-EH80), at a different concentration (from 0 to $2.5 \mathrm{mg} / \mathrm{mL}$ ) $\left(2 \mathrm{~mL}\right.$ ), was vigorously mixed with $1.7 \mathrm{~mL}$ distilled water and $0.1 \mathrm{~mL}$ of $2 \mathrm{mM} \mathrm{FeCl}_{2}$. The reaction was initiated by adding $0.2 \mathrm{~mL}$ of $5 \mathrm{mMferrozine}$, and the mixture was shaken vigorously and left standing at room temperature for $10 \mathrm{~min}$. A control test was performed with distilled water but without a test sample; the solution without ferrozine added was used as a control. The ferrous ion chelating ability was determined by measuring the absorbance at $562 \mathrm{~nm}$ using a spectrophotometer (Hitachi U-3010, Tokyo, Japan). The ferrous ion chelating ability was calculated as follows [36]:

Metal chelating activity $(\%)=[1-$ (absorbance of sample - absorbance of blank) / absorbance of control] $\times 100$

\subsection{ABTS Radical Scavenging Assay}

The ABTS radical cation $\left(\mathrm{ABTS}^{+}{ }^{+}\right)$solution was prepared by reacting a $7 \mathrm{mM}$ ABTS solution with $2.45 \mathrm{mM}$ potassium persulphate in the dark at room temperature for $12 \mathrm{~h}$. The ABTS $\bullet^{+}$solution was then diluted with $95 \%$ ethanol to obtain an absorbance of $0.7 \pm 0.02$ at $735 \mathrm{~nm}$. Each sample (PSPs, PSPs-EH20 and PSPs-EH80) was added to $2 \mathrm{~mL} \mathrm{ABTS \bullet}{ }^{+}$solution and mixed vigorously. All measurements were taken after at least $6 \mathrm{~min}$. The total antioxidant activity was determined by measuring the absorbance at $735 \mathrm{~nm}$ with a spectrophotometer (Hitachi U-3010). A control test was performed with distilled water but without a test sample; the solution, without ABTS added, was used as a control. The ABTS $\bullet^{+}$radical scavenging activity was calculated as follows [37]:

ABTS radical scavenging activity $(\%)=[1-($ absorbance of sample absorbance of blank)/absorbance of control] $\times 100$

\subsection{DPPH Radical Scavenging Assay}

The DPPH free radical scavenging activity was determined by Yang's method, with some modifications [38]. Each sample (PSPs, PSPs-EH20 and PSPs-EH80), at a different concentration (from 0 to $2.5 \mathrm{mg} / \mathrm{mL}$ ) in $2 \mathrm{~mL}$ distilled water was mixed with $2 \mathrm{~mL} 1 \mathrm{mM}$ DPPH solution (dissolved in methanol). The mixture was shaken vigorously and then left to stand in the dark for $30 \mathrm{~min}$. The absorbance of the control sample was accomplished by replacing the test sample with methanol. The DPPH radical scavenging activity was determined by measuring the absorbance at $517 \mathrm{~nm}$ using a spectrophotometer (Hitachi U-3010). A control test was performed with distilled water, but without a test sample; the solution without DPPH added was used as a control. The DPPH radical scavenging activity was calculated as follows:

DPPH radical scavenging activity $(\%)=[1-($ absorbance of sample absorbance of blank)/absorbance of control $] \times 100$

\subsection{Determination of Molecular Weight}

The determination of molecular weight followed Lee's and Zhang's method, with some modifications $[39,40]$. The PSPs and PSPs-EH sample fractions were determined by gel filtration with the column packed with Sepharose CL-6B $(1.6 \times 100 \mathrm{~cm})$, and operated at a flow rate of $0.5 \mathrm{~mL} / \mathrm{min}$ in distilled water. Standard dextrans T-200, T-150, T-70, T-40 and T-10 were passed through a Sepharose CL-6B column; the elution volumes were then plotted against the logarithms of the respective molecular weights. The elution volumes of PSPs and PSPs-EH samples were plotted on the same graph; the molecular weights of PSPs and PSPs-EH were thereby determined. The hydrolysis rate was calculated using the following formula:

Hydrolysis rate $(\%)=1-[($ peak area after hydrolysis/peak area before hydrolysis $)] \times 100$ 


\subsection{FT-IR Spectroscopy}

The PSPs and PSPs-EH were individually incorporated into KBr (spectroscopic grade) and pressed into a $1 \mathrm{~mm}$ pellet. The spectra were recorded at absorbance ranging from 4000 to $500 \mathrm{~cm}^{-1}$ using an FT-IR spectrometer (FT-IR 8400S, Shimadzu, Kyoto, Japan). The FT-IR spectroscopy was determined by Leung's method, with some modifications [41].

\subsection{Cell Culture}

Human keratinocyte (HaCaT) cell lines were purchased from the American Type Culture Collection (Manassas, VA, USA). HaCaT cells were cultured in Dulbecco's Modified Eagle's Medium (DMEM) with 10\% fetal bovine serum (FBS) (Life Technologies, Rockville, MD, USA), $100 \mu \mathrm{g} / \mathrm{mL}$ of streptomycin, and 100 units/mL of penicillin (HyClone, Thermo Scientific, Rockford, IL, USA). Cells were maintained in a humidified $5 \% \mathrm{CO}_{2}$ atmosphere at $37^{\circ} \mathrm{C}[42]$.

\subsection{MTT Assay}

Cell viability was determined by using the MTT assay. HaCaT cells at a density of $10^{4}$ cells/well in 96-well plates were pretreated with various concentrations of PSPs and PSPs-EH80 (50-125 $\mu \mathrm{g} / \mathrm{mL})$ for $24 \mathrm{~h}$, and then incubated with $20 \mathrm{mM}$ AAPH for $4 \mathrm{~h}$. For the MTT assay, $20 \mu \mathrm{L}$ of MTT solution $(5 \mathrm{mg} / \mathrm{mL})$ was added to each well of a 96-well plate and incubated for $2 \mathrm{~h}$. The supernatant was then removed, and the formazan crystals so obtained were dissolved in $200 \mu \mathrm{L}$ of dimethyl sulfoxide, and quantified by measuring the optical density at $570 \mathrm{~nm}$ using an ELISA reader (Thermo). The effect of PSPs on cell viability was assessed as the percent of viable cells compared with the vehicle-treated control cells, which were arbitrarily assigned a viability of $100 \%$. The assay was performed in triplicate at each concentration [29].

\subsection{Intracellular ROS Detection}

The intracellular accumulation of ROS was detected by fluorescence microscopy using DCFH-DA. The HaCaT cells $\left(3 \times 10^{5}\right.$ cells / well) were cultured in a 6-well plate in DMEM supplemented with $10 \%$ FBS; the culture medium was renewed when the cells reached $80 \%$ confluence. After PSPs and PSPs-EH80 treatment $(50-125 \mu \mathrm{g} / \mathrm{mL})$ for $24 \mathrm{~h}$ and AAPH treatment $(20 \mathrm{mM})$ for $4 \mathrm{~h}$, the cells were incubated with $10 \mu \mathrm{M}$ DCFH-DA in the culture medium at $37^{\circ} \mathrm{C}$ for $30 \mathrm{~min}$. The acetate groups on DCFH-DA were then removed by an intracellular esterase, trapping the probe inside the cells. The cells were then washed with warm PBS buffer. ROS production can be measured by the changes in fluorescence due to the intracellular accumulation of 2,7-dichlorofluorescin-diacetate (DCF) caused by the oxidation of DCFH. The DCF fluorescence was measured using a fluorescence microscope (Olympus $1 \times 71$ at $40 \times$ magnification, Tokyo, Japan) [43].

\subsection{Statistical Analysis}

All experiments were carried out in triplicate. All of the data are presented as mean \pm standard deviation (SD); differences among the groups were subjected to a one-way ANOVA (analysis of variance) followed by Duncan's multiple range, Tukey's HSD or Fisher's tests (SPSS version 16.0); when statistically significant, they were accepted when a $p$-value $<0.05$.

\section{Conclusions}

In this study, the functional groups in PSPs-EH80 did not change during the process of enzymatic hydrolysis with $\beta$-1,3-glucanase; in turn, this process could enhance the antioxidant activity of polysaccharides by modification of their molecular weight. PSPs-EH80 also inhibited the oxidative damage induced by ROS on HaCaT cells. In summary, using $\beta-1,3$-glucanase in the specific hydrolysis of $T$. versicolor polysaccharides is suitable for enhancing its antioxidative capacity. 
Acknowledgments: Financial support from the Cheng Ching General Hospital, Taichung, Taiwan, Republic of China (CCGH-DYU-103-001) is gratefully acknowledged.

Author Contributions: Chang-Wei Hsieh: Research Project Moderator, research results analysis, written and published. Ching-Hua Yeh: Research Project Moderator. Chao-Kai Chang: Design and planning experiments Module, data analysis. Mei-Hsin Jhan: Experimental operation. Chia-Chun Tsai: Experimental operation. Ching-Tian Kao: Laboratory and Research Project Moderator.

Conflicts of Interest: The authors declare no conflict of interest.

\section{References}

1. Hor, S.Y.; Ahmad, M.; Farsi, E.; Lim, C.P.; Asmawi, M.Z.; Yam, M.F. Acute and subchronic oral toxicity of Coriolus versicolor standardized water extract in Sprague-Dawley rats. J. Ethnopharmacol. 2011, 137, 1067-1076. [CrossRef] [PubMed]

2. Sun, X.; Sun, Y.; Zhang, Q.; Zhang, H.; Yang, B.; Wang, Z.; Zhu, W.; Li, B.; Wang, Q.; Kuang, H. Screening and comparison of antioxidant activities of polysaccharides from Coriolus versicolor. Int. J. Biol. Macromol. 2014, 69, 12-19. [CrossRef] [PubMed]

3. Yang, L.; Zhang, L.-M. Chemical structural and chain conformational characterization of some bioactive polysaccharides isolated from natural sources. Carbohydr. Polym. 2009, 76, 349-361. [CrossRef]

4. Harikrishnan, R.; Kim, M.C.; Kim, J.S.; Balasundaram, C.; Heo, M.S. Effect of Coriolus versicolor supplemented diet on innate immune response and disease resistance in kelp grouper Epinephelus bruneus against Listonella anguillarum. Fish Shellfish Immunol. 2012, 32, 339-344. [CrossRef] [PubMed]

5. Yeung, J.H.K.; Or, P.M.Y. Polysaccharide peptides from Coriolus versicolor competitively inhibit model cytochrome p450 enzyme probe substrates metabolism in human liver microsomes. Phytomedicine 2012, 19, 457-463. [CrossRef] [PubMed]

6. Volman, J.J.; Helsper, J.P.; Wei, S.; Baars, J.J.; van Griensven, L.J.; Sonnenberg, A.S.; Mensink, R.P.; Plat, J. Effects of mushroom-derived beta-glucan-rich polysaccharide extracts on nitric oxide production by bone marrow-derived macrophages and nuclear factor-kappab transactivation in Caco-2 reporter cells: Can effects be explained by structure? Mol. Nutr. Food Res. 2010, 54, 268-276. [CrossRef] [PubMed]

7. Zhang, N.; Chen, H.; Ma, L.; Zhang, Y. Physical modifications of polysaccharide from Inonotus obliquus and the antioxidant properties. Int. J. Biol. Macromol. 2013, 54, 209-215. [CrossRef] [PubMed]

8. Liu, D.; Sheng, J.; Li, Z.; Qi, H.; Sun, Y.; Duan, Y.; Zhang, W. Antioxidant activity of polysaccharide fractions extracted from Athyrium multidentatum (Doll.) Ching. Int. J. Biol. Macromol. 2013, 56, 1-5. [CrossRef] [PubMed]

9. Yan, J.K.; Li, L.; Wang, Z.M.; Leung, P.H.; Wang, W.Q.; Wu, J.Y. Acidic degradation and enhanced antioxidant activities of exopolysaccharides from Cordyceps sinensis mycelial culture. Food Chem. 2009, 117, 641-646. [CrossRef]

10. Li, B.; Liu, S.; Xing, R.; Li, K.; Li, R.; Qin, Y.; Wang, X.; Wei, Z.; Li, P. Degradation of sulfated polysaccharides from Enteromorpha prolifera and their antioxidant activities. Carbohydr. Polym. 2013, 92, 1991-1996. [CrossRef] [PubMed]

11. Zhao, T.; Mao, G.; Mao, R.; Zou, Y.; Zheng, D.; Feng, W.; Ren, Y.; Wang, W.; Zheng, W.; Song, J.; et al. Antitumor and immunomodulatory activity of a water-soluble low molecular weight polysaccharide from Schisandra chinensis (Turcz.) Baill. Food Chem. Toxicol. 2013, 55, 609-616. [CrossRef] [PubMed]

12. Kim, S.; Rajapakse, N. Enzymatic production and biological activities of chitosan oligosaccharides (COS): A review. Carbohydr. Polym. 2005, 62, 357-368. [CrossRef]

13. Considine, T.; Patel, H.A.; Anema, S.G.; Singh, H.; Creamer, L.K. Interactions of milk proteins during heat and high hydrostatic pressure treatments-A review. Innov. Food Sci. Emerg. Technol. 2007, 8, 1-23. [CrossRef]

14. Meyer, K.; Dubos, R.; Smyth, E.M. The hydrolysis of the polysaccharide acids of vitreous humor, of umbilical cord, and of Streptococcus by the autolytic enzyme of Pneumococcus. J. Biol. Chem. 1937, 118, 71-78.

15. Chesters, C.G.C.; Bull, A.T. The enzymic degradation of laminarin. 1. The distribution of laminarinase among micro-organisms. Biochem. J. 1963, 86, 28-31. [CrossRef] [PubMed]

16. Qiao, D.; Ke, C.; Hu, B.; Luo, J.; Ye, H.; Sun, Y.; Yan, X.; Zeng, X. Antioxidant activities of polysaccharides from Hyriopsis cumingii. Carbohydr. Polym. 2009, 78, 199-204. [CrossRef]

17. Li, X.M.; Li, X.L.; Zhou, A.G. Evaluation of antioxidant activity of the polysaccharides extracted from Lycium barbarum fruits in vitro. Eur. Polym. J. 2007, 43, 488-497. [CrossRef] 
18. Liu, W.; Wang, H.; Pang, X.; Yao, W.; Gao, X. Characterization and antioxidant activity of two low-molecular-weight polysaccharides purified from the fruiting bodies of Ganoderma lucidum. Int. J. Biol. Macromol. 2010, 46, 451-457. [CrossRef] [PubMed]

19. Yue, C.; Chen, J.; Hou, R.; Liu, J.; Li, X.; Gao, Z.; Liu, C.; Wang, D.; Lu, Y.; Li, H.; et al. Effects of selenylation modification on antioxidative activities of Schisandra chinensis polysaccharide. PLoS ONE 2015, 10, e0134363. [CrossRef] [PubMed]

20. Wang, J.H.; Xu, J.L.; Zhang, J.C.; Liu, Y.; Sun, H.J.; Zha, X. Physicochemical properties and antioxidant activities of polysaccharide from floral mushrooms cultivated in Huangshan Mountain. Carbohydr. Polym. 2015, 131, 240-247. [CrossRef] [PubMed]

21. Behera, B.C.; Verma, N.; Sonone, A.; Makhija, U. Evaluation of antioxidant potential of the cultured mycobiont of a lichen Usnea ghattensis. Phytother. Res. 2005, 19, 58-64. [CrossRef] [PubMed]

22. Chen, Y.; Xie, M.-Y.; Nie, S.-P.; Li, C.; Wang, Y.-X. Purification, composition analysis and antioxidant activity of a polysaccharide from the fruiting bodies of Ganoderma atrum. Food Chem. 2008, 107, 231-241. [CrossRef]

23. Miliauskas, G.; Venskutonis, P.R.; van Beek, T.A. Screening of radical scavenging activity of some medicinal and aromatic plant extracts. Food Chem. 2004, 85, 231-237. [CrossRef]

24. Shao, P.; Chen, X.; Sun, P. Improvement of antioxidant and moisture-preserving activities of Sargassum horneri polysaccharide enzymatic hydrolyzates. Int. J. Biol. Macromol. 2015, 74, 420-427. [CrossRef] [PubMed]

25. Luo, A.; He, X.; Zhou, S.; Fan, Y.; Luo, A.; Chun, Z. Purification, composition analysis and antioxidant activity of the polysaccharides from Dendrobium nobile Lindl. Carbohydr. Polym. 2010, 79, 1014-1019. [CrossRef]

26. Sun, L.; Wang, C.; Shi, Q.; Ma, C. Preparation of different molecular weight polysaccharides from Porphyridium cruentum and their antioxidant activities. Int. J. Biol. Macromol. 2009, 45, 42-47. [CrossRef] [PubMed]

27. Černá, M.; Barros, A.S.; Nunes, A.; Rocha, S.1.M.; Delgadillo, I.; Čopíková, J.; Coimbra, M.A. Use of FT-IR spectroscopy as a tool for the analysis of polysaccharide food additives. Carbohydr. Polym. 2003, 51, 383-389. [CrossRef]

28. Huang, S.Q.; Li, J.W.; Li, Y.Q.; Wang, Z. Purification and structural characterization of a new water-soluble neutral polysaccharide GLP-F1-1 from Ganoderma lucidum. Int. J. Biol. Macromol. 2011, 48, 165-169. [CrossRef] [PubMed]

29. Cui, Y.; Kim, D.S.; Park, S.H.; Yoon, J.A.; Kim, S.K.; Kwon, S.B.; Park, K.C. Involvement of ERK and p38 map kinase in AAPH-induced Cox-2 expression in HaCat cells. Chem. Phys. Lipids 2004, 129, 43-52. [CrossRef] [PubMed]

30. Roche, M.; Tarnus, E.; Rondeau, P.; Bourdon, E. Effects of nutritional antioxidants on AAPH- or AGES-induced oxidative stress in human SW872 liposarcoma cells. Cell. Biol. Toxicol. 2009, 25, 635-644. [CrossRef] [PubMed]

31. Zhang, H.; Chen, T.; Jiang, J.; Wong, Y.S.; Yang, F.; Zheng, W. Selenium-containing allophycocyanin purified from selenium-enriched Spirulina platensis attenuates AAPH-induced oxidative stress in human erythrocytes through inhibition of ROS generation. J. Agric. Food Chem. 2011, 59, 8683-8690. [CrossRef] [PubMed]

32. Lopez, E.; Arce, C.; Oset-Gasque, M.J.; Canadas, S.; Gonzalez, M.P. Cadmium induces reactive oxygen species generation and lipid peroxidation in cortical neurons in culture. Free Radic. Boil. Med. 2006, 40, 940-951. [CrossRef] [PubMed]

33. Lekounougou, S.; Mounguengui, S.; Dumarçay, S.; Rose, C.; Courty, P.E.; Garbaye, J.; Gérardin, P.; Jacquot, J.P.; Gelhaye, E. Initial stages of Fagus sylvatica wood colonization by the white-rot basidiomycete Trametes versicolor: Enzymatic characterization. Int. Biodeterior. Biodegrad. 2008, 61, 287-293. [CrossRef]

34. Hung, M.C.; Tsai, C.C.; Hsu, T.H.; Liang, Z.C.; Lin, F.Y.; Chang, S.L.; Ho, W.J.; Hsieh, C.W. Biological activities of the polysaccharides produced from different sources of Xylaria nigripes (Ascomycetes), a Chinese medicinal fungus. Int. J. Med. Mushrooms 2015, 17, 141-150. [CrossRef] [PubMed]

35. Almirall, M.; Esteve-Garcia, E. In vitro stability of a $\beta$-glucanase preparation from Trichoderma longibrachiatum and its effect in a barley based diet fed to broiler chicks. Anim. Feed Sci. Technol. 1995, 54, 149-158. [CrossRef]

36. Nadaroglu, H.D.; Demir, N.; Demir, Y. Antioxidant and radical scavenging activities of capsules of caper (Capparis spinosa). Asian J. Chem. 2009, 21, 5123-5134.

37. Re, R.; Pellegrini, N.; Proteggente, A.; Pannala, A.; Yang, M.; Rice-Evans, C. Antioxidant activity applying an improved ABTS radical cation decolorization assay. Free Radic. Biol. Med. 1999, 26, 1231-1237. [CrossRef] 
38. Yang, B.; Zhao, M.; Shi, J.; Yang, N.; Jiang, Y. Effect of ultrasonic treatment on the recovery and DPPH radical scavenging activity of polysaccharides from longan fruit pericarp. Food Chem. 2008, 106, 685-690. [CrossRef]

39. Lee, J.S.; Kwon, J.S.; Yun, J.S.; Pahk, J.W.; Shin, W.C.; Lee, S.Y.; Hong, E.K. Structural characterization of immunostimulating polysaccharide from cultured mycelia of Cordyceps militaris. Carbohydr. Polym. 2010, 80, 1011-1017. [CrossRef]

40. Zhang, L.; Koyyalamudi, S.R.; Jeong, S.C.; Reddy, N.; Bailey, T.; Longvah, T. Immunomodulatory activities of polysaccharides isolated from Taxillus chinensis and Uncaria rhyncophylla. Carbohydr. Polym. 2013, 98, 1458-1465. [CrossRef] [PubMed]

41. Leung, P.H.; Zhao, S.; Ho, K.P.; Wu, J.Y. Chemical properties and antioxidant activity of exopolysaccharides from mycelial culture of Cordyceps sinensis fungus CS-HK1. Food Chem. 2009, 114, 1251-1256. [CrossRef]

42. Park, J.H.; Kim, M.S.; Jeong, G.S.; Yoon, J. Xanthii fructus extract inhibits TNF- $\alpha /$ IFN- $\gamma$-induced Th2-chemokines production via blockade of NF-kB, Stat1 and p38-MAPK activation in human epidermal keratinocytes. J. Ethnopharmacol. 2015, 171, 85-93. [CrossRef] [PubMed]

43. Kumar, K.J.; Yang, H.L.; Tsai, Y.C.; Hung, P.C.; Chang, S.H.; Lo, H.W.; Shen, P.C.; Chen, S.C.; Wang, H.M.; Wang, S.Y.; et al. Lucidone protects human skin keratinocytes against free radical-induced oxidative damage and inflammation through the up-regulation of HO-1/NRF2 antioxidant genes and down-regulation of NF-кB signaling pathway. Food Chem. Toxicol. 2013, 59, 55-66. [CrossRef] [PubMed]

Sample Availability: Samples of the Trametes versicolor are available from the authors.

(C) 2016 by the authors; licensee MDPI, Basel, Switzerland. This article is an open access article distributed under the terms and conditions of the Creative Commons Attribution (CC-BY) license (http://creativecommons.org/licenses/by/4.0/). 